\title{
Mycosphere Essays 14: Assessing the aggressiveness of plant pathogenic Botryosphaeriaceae
}

\author{
Manawasinghe $\mathrm{IS}^{1,2}$, Phillips $\mathrm{AJL}^{3}$, Hyde $\mathrm{KD}^{2}$, Chethana $\mathrm{KWT}^{1,2}$, Zhang $\mathrm{W}^{1,4}$, \\ Zhao $\mathrm{WS}^{4}$, Yan JY' ${ }^{1}$,i XH ${ }^{1, *}$
}

${ }^{1}$ Institute of Plant and Environment Protection, Beijing Academy of Agriculture and Forestry Sciences, Beijing 100097, People's Republic of China.

${ }^{2}$ Center of Excellence in Fungal Research, Mae Fah Luang University, Chiang Rai 57100, Thailand.

${ }^{3}$ University of Lisbon, Faculty of Sciences, Biosystems and Integrative Sciences Institute (BioISI), Campo Grande, 1749-016 Lisbon, Portugal.

${ }^{4}$ College of Plant Protection, China Agricultural University, Beijing 100193, China.

Manawasinghe IS, Phillips AJL, Hyde KD, Chethana KWT, Zhang W, Zhao WS, Yan JY, Li XH 2016 - Mycosphere Essays 14: Assessing the aggressiveness of plant pathogenic Botryosphaeriaceae. Mycosphere 7(7), 883-892, Doi 10.5943/mycosphere/si/1b/7

\begin{abstract}
Species of Botryosphaeriaceae (Dothideomycetes, Ascomycota) have been reported as endophytes, pathogens and saprobes on a wide range of plants. Their roles in different life forms are not well-defined and should be studied in more detail. It is of interest to understand how these fungi become pathogenic on living tissues. Previous studies have proposed that the pathogenicity of botryosphaeriaceous species is triggered by the changes in environmental conditions. It is assumed that, external stimuli caused by above ground and below ground factors, extensive physical damage due to management practices or from pests, impose stress on the host plant. Due to these stresses, these botryosphaeriaceous taxa activate their biochemical mechanisms and become plant pathogens, causing disease. These diseases may ultimately result in plant death and thus cause economic losses. Since the aggressiveness of Botryosphaeriaceae species depends on changes in their surrounding environmental factors, species in this group are regarded as opportunistic pathogens. Nevertheless, it is still debatable, whether it is the changing environment that triggers pathogenicity of Botryosphaeriaceae, or disease development is a result of weakening of the host defences. Therefore, it is important to design experiments to understand the factors involved in pathogenesis.
\end{abstract}

Key words - Botryosphaeria dieback - endophytic fungi - opportunistic fungal pathogens pathogenicity test - virulence

\section{Introduction}

The family Botryosphaeriaceae encompasses a range of diverse fungi that are pathogens, endophytes or saprobes on a wide range of hosts. They are found in all geographic and climatic areas of the world, with the exception of the polar regions (Crous et al. 2007, Rodas et al. 2009, Wunderlich et al. 2011, Phillips et al. 2013, Alves et al. 2014, Hyde et al. 2014, Lorenzini et al. 2015, Trakunyingcharoen et al. 2015). These fungi are categorized as pathogens of woody hosts 
that penetrate their hosts through natural openings, such as stomata, lenticels, wounds, infected twigs, stems, roots and leaves (Schoeneweiss 1981). They are thought to exist in a latent state inside the host tissues for an extended period without causing any symptoms (Smith et al. 1996a). Some studies have proposed that when plants become stressed due to extreme environmental conditions, both above and below ground, or if management practices or pests, physically damage the host, these latent infections become active and result in serious diseases (Schoeneweiss 1981, Smith et al. 1996a, Slippers \& Wingfield 2007). These diseases include cankers, dieback, fruit rot, gummosis, leaf spots and even plant death (Rodas et al. 2009, Xu et al. 2015) and they are the cause of important emerging diseases (Alves et al. 2014, Machado et al. 2014, Netto et al. 2014) . Within the family their ecological role varies with species. For example, species such as Diplodia seriata, Lasiodiplodia species, and Neofusicoccum parvum are reported to be pathogenic on many hosts (Phillips et al. 2013, Chen et al. 2014, Netto et al. 2014, Li et al. 2015, Linaldeddu et al. 2015, Farr \& Rossman 2016) whileDothiorella dulcispinae and Dothiorella pretoriensis have been reported as weak pathogens (Jami et al. 2013, Phillips et al. 2013).

The ecological role (as endophytes, pathogens or saprobes) of members of the family Botryosphaeriaceae can change according to the local ecosystem. Therefore, in this review, we will regard species of Botryosphaeriaceae as opportunistic plant fungal pathogens, and focus how their pathogenicity varies with environmental factors. We discuss (1) the terminology used to describe pathogenicity, (2) the family Botryosphaeriaceae, (3) the effects of the environmental on hostpathogen interactions, (4) the possibility of phytotoxin-induced pathogenicity and (5) pathogenicity and aggressiveness assays.

\section{Terminology used to describe pathogenicity}

Researchers identify fungal taxa from different substrates, for various reasons. For example, they may want to know the cause of a disease, the identity of the fungus from a quarantine perspective, the ecological roles of taxa in the environment, the names for biodiversity inventories, or from curiosity. Once an organism is identified, some of the questions that arise are, "What does this organism do?" or "Will it be harmful?" To answer such questions and to describe the effects of living organisms on another, various terms have been used. The term "pathogen" describes if an organism is capable of causing a disease in another organism. Several terms are used to describe the level of damage caused by a pathogen including "offensive", "defensive" (Smith 1914), "pure saprobe", "pure parasite", "half parasite" (Zinsser \& Bayne- Jones1939, D'Arcy et al. 2011) "virulence", "pathogenicity" and "aggressiveness (D'Arcy et al. 2011). Plant pathologists and specialists in related fields have provided definitions for these terms. According to those definitions, "pathogenicity" is the capacity of a microbe to produce a disease or to cause damage to a host. Virulence and aggressiveness relate to the relative capacity of a microbe to cause damage to a host (degree of pathogenicity) (D'Arcy et al. 2011). Certain host-pathogen relationships have a gene-for-gene interaction in which the plant produces resistance genes against a corresponding virulence gene of the pathogen (McDonald 2004, Pariaud et al. 2009). When the pathogens are host-specific, the term "virulence" is used as the quantitative measure of pathogenicity. On the other hand, aggressiveness refers to a quantitative variation of pathogenicity on susceptible hosts without any restriction related to specificity (Pariaud et al. 2009).

"Pathogenicity" is a qualitative character that is used to describe the character of a particular organism that has the ability to cause disease. For such an organism, the level of harmfulness on the host can be expressed as aggressiveness or virulence, which is the quantitative trait. Since there is no evidence to suggest a gene-for-gene interaction between the host and species in Botryosphaeriaceae they are considered as non host-specific. For example, Lasiodiplodia theobromae has been reported as an aggressive pathogen on avocado, banana, barbados cherry, cashew, citrus, coconut palm, custard apple, grapevine, guava, mango, muskmelon, passion fruit, soursop, and watermelon in Brazil (Netto et al. 2014). In grapevines, dieback is caused by several different species in different countries (Úrbez-Torres et al. 2010a, b, 2011, Marques et al. 2013, Whitelaw-Weckert et al. 2013, Yan et al. 2013, Linaldeddu et al. 2015). Therefore, in this essay 
we use the term "aggressiveness" rather than "virulence" to describe the degree of pathogenicity of species in Botryosphaeriaceae.

\section{The family Botryosphaeriaceae}

The family Botryosphaeriaceae (Dothideomycetes, Ascomycota) was introduced by Theissen \& Sydow (1918). Members of this family occur in most parts of the world in various ecological niches (Liu et al. 2012, Phillips et al. 2013). They are characterized by their large, ovoid to oblong hyaline or coloured and septate or aseptate ascospores. Botryosphaeriaceae species occur in wide a range of habits as saprobes, endophytes and parasites (Begoude et al. 2011, Úrbez-Torres 2011, Phillips et al. 2013). Species are widely distributed and occur in a range of host plants, including dicotyledonous, monocotyledonous and gymnosperms. They live on twigs and woody branches, herbaceous leaves, stems and culms of grasses, in the thalli of lichens and even on sea grasses (Barr 1987, Mohali et al. 2009, Begoude et al. 2011, Liu et al. 2012).

Species of Botryosphaeriaceae are well-known as endophytes. Endophytic fungi are ubiquitous and diverse in host plants (Faeth \& Fagan 2002, Hyde \& Soytong 2008, Nair \& Padmavathy 2014). Some endophytes are considered to provide crucial services to the host. For example, some are responsible for carbohydrate exchange, protection from other pathogens and for increasing the rate at which sub-optimal tissues are discarded (Faeth \& Fagan 2002, Hantsch et al. 2014, Nair \& Padmavathy 2014). Many species of the Botryosphaeriaceae are considered to be Class III endophytes (Smith et al. 1996a, Sakalidis et al. 2011). They have the potential to become latent or opportunistic pathogens. It is thought that when plants are stressed due to various factors, class III endophytes become active and cause disease (Sakalidis et al. 2011).

Some Botryosphaeriaceous taxa live as saprobes on dead material (Jeewon et al. 2013). They recycle organic and inorganic material enhancing the nutrient level of soil. It has been reported that Botryosphaeriaceae species can survive on plant debris until they have an opportunity to invade a suitable plant host (Jeewon et al. 2013). However, the mechanism that changes a saprobe to become a pathogen has not yet been determined. This phenomenon might be due to changes in the surrounding environment, such as an increase in temperature, high light intensity, low soil temperature and lack of available organic compounds in soil. All of these factors need to be studied.

Jami et al. (2013) proposed that species of Botryosphaeriaceae could be used as model organisms to understand the dispersal patterns of latent pathogens. As latent pathogens, they can be unintentionally spread around the world on seeds, cuttings or even in fruits (Begoude et al. 2011). Even though they are endophytes on a wide range of hosts, their role as plant pathogens has received greater attention. The relationship between endophytes and pathogens in Botryosphaeriaceae is presently unclear. Some experiments have been conducted in the last few years to understand the relationships between endophytic and pathogenic life-styles. The following section gives some indication of the effect of the environment on aggressiveness in Botryosphaeriaceae.

\section{Effect environment on host-pathogen interactions}

The main questions that arise when it comes to diseases caused by species of Botryosphaeriaceae are, "How do these fungi become pathogenic to their host plants?" and "What alters their life mode from endophyte to pathogen?" It is still not known if the environment directly influences the fungi to become pathogenic or if they become pathogenic once the host plant loses vigour due to changes in environmental conditions. Thus, it is debatable whether the change from endophytic to a pathogenic life mode is a result of the direct influence of the environment on the fungus or due to a loss of resistance by the host plant (Slippers \& Wingfield 2007, Úrbez-Torres 2010a, b, c, Álvarez-Loayza et al. 2011). However, most studies have focused on factors that alter host susceptibility via stressing the plant, rather than the direct effects of the environment on the fungi. 
To understand the effect of climate upon aggressiveness of a taxon, it is necessary to carry out continuous field evaluations over consecutive years (Pariaud et al. 2009). In Botryosphaeriaceae, there have been few long term field studies aimed at understanding how changes in the environment affect aggressiveness. Among the studies on Botryosphaeriaceae, only a few highlight the effect of environment on disease development. The influence of light intensity on Diplodia mutila and the transition from an endosymbiotic to a pathogenic lifestyle was shown by Álvarez-Loayza et al. (2011) in a common tropical tree, Iriartea deloidea. Low light favours endosymbiotic development, constraining recruitment of endophyte-infested seedlings to shaded understory by reducing seedling survival in direct light. The pathogenicity of $D$. mutila under higher light intensity is believed to result from light-induced production of hydrogen peroxide. This might trigger hypersensitivity, cell death, and tissue necrosis in the host (Álvarez-Loayza et al. 2011).

The effect of temperature on fungal growth and disease development has been reported in several studies. Sánchez et al. (2003) highlighted the temperature-growth relationship on D. mutila, Dothiorella sarmentorum and Botryosphaeria dothidea. Their study showed that the optimum temperature for growth of these taxa is $20-25^{\circ} \mathrm{C}$. Pathogenicity tests revealed that there was a significant difference in lesion length at these temperatures. At the optimal temperature for growth, Dothiorella sarmentorum formed larger lesions than at sub- or super-optimal temperatures. With an increase in temperature, all three species caused larger lesions (Félix et al. 2016). This study demonstrated that with increasing temperature, over the range of $25-37^{\circ} \mathrm{C}$, there was a corresponding increase in the production of pathogenesis-related proteins by Lasiodiplodia theobromae. This suggested the possibility of temperature induced pathogenicity of L. theobromae. With increased temperatures and global warming, pests and diseases could expand their geographical ranges and plants could be exposed to more stress (Piao et al. 2010). Global warming may result in an increased chance of infection by opportunistic Botryosphaeriaceae species.

Several studies have been conducted to understand the effect of water stress on disease development by botryosphaeriaceous taxa (Desprez-Loustau et al. 2006). Ragazzi et al. (1999a, b) showed that canker development by D. mutila on Quercus robur seedlings was enhanced under water stress. Mareeswaran et al. (2015) reported that tea leaf spot, caused by Macrophoma theicola, is most severe in drought susceptible areas where soil conditions are poor. Such conditions would be expected to impose severe drought stress on the host and this would likely make it more susceptible to disease. Paoletti et al. (2007) tested the effect of ozone on disease expression by Diplodia corticola. Their study demonstrated that exposure of one-year-old cork oak seedlings to ozone increased the development of lesions by D. corticola on leaves. The same study suggested that ozone and drought are the major abiotic factors affecting plants in Mediterranean forests leading to increased levels of fungal infections. Wingfield et al. (2011) stated that the aggressiveness of botryosphaeriaceous taxa would increase once the plant moves away from its native environment. As an example they showed that Acacia mearnsii trees introduced into South Africa have a relatively lower endophytic population compared to plants in their native populations. Their study indicated that species of Botryosphaeriaceae are major stress-related pathogens in South African Acacia species, but this statement was based on previous disease reports and did not provide any experimental evidence.

Physical damage to the host has been implicated in the epidemiology of diseases caused by Botryosphaeriaceae species. Pruning can stress the plant and simultaneously pruning wounds are highly susceptible to infection by botryosphaeriaceous taxa. Disease severity increases when pruning practices are carried out with the onset of rainfall (Slippers \& Wingfield 2007, ÚrbezTorreset al. 2010c, Amponsah et al. 2012). Wounds resulting from pest damage or severe environmental conditions such as heavy snowfall, storms and hail are also reported to increase susceptibility to infection by Botryosphaeriaceae species (Slippers \& Wingfield 2007).

Hartill \& Everett (2002) carried out an interesting study on avocado fruit rot, which is caused by Botryosphaeriaceae, Colletotrichum, and Phomopsis species. Those species were identified as both endophytes and pathogens of avocado. They suggested possible pathways for 
fruit infection as follows: 1) infections can take place at flowering stage and remain dormant until fruit ripening, 2) during ripening stage the infection sites are less resistant, thus increase the possibility for infection, 3) the pathogen remains as an endophyte in pedicels and twigs and then grows into the fruits, 4) airborne spores or hyphal fragments directly infect twigs and fruit. They provided evidence to support the third pathway, but the evidence was insufficient to conclude how these fungi become pathogenic on fruits. Nevertheless, they point out the phase of "phellophytes"; fungi that live in the outer layer of the bark and infect the fruit when physical damage occurs. This study revealed that Botryosphaeria dothidea and Neofusicoccum parvum, the causal agents of avocado fruit rot, occur at much greater frequencies in the extra cambial tissues than in the xylem (Hartill \& Everett 2002).

Several experiments have suggested that Botryosphaeriaceae can transform from their endophytic phase to become pathogenic (Smith et al. 1996a,b, Sakalidis et al. 2011). Such studies have suggested that when the host plant is stressed, the fungi can colonize the plant (Slippers \& Wingfield 2007). Factors that are considered to trigger Botryosphaeriaceae species to become pathogenic from their endophytic or saprobic phase could be changes in environmental conditions, such as high light intensity, high or low temperature, high relative humidity and soil conditions (drought, water-logging or low soil temperature) (Agrios 2005). Abiotic factors associated with the plants are nutrient deficiency and physical damage. Competition among plants can also act as the factors triggering this transition (Slippers \& Wingfield 2007, Amponsah et al. 2011, Wunderlich et al. 2011). In addition, environmental factors can also affect the fungal pathogenic community. For example, a pathogenic fungus could be living in the form of an endophyte or a saprobe. When the surrounding microenvironment changes (often temperature and moisture), they have to compete with other microbes for their survival. Natural selection then takes place, which allows the ability of microbes to invade the plant, triggering their new life style, becoming pathogenic, continuing their life cycles as a pathogen, and thus surviving (Casadevall 2009). This series of events may also apply to species of Botryosphaeriaceae and possibly explain how they change their life-style from saprobic or endophytic to pathogenic.

In view of the above facts, it is debatable if environmental factors actually trigger the aggressiveness of Botryosphaeriaceae species. It is more likely that disease development is a result of increased host susceptibility. Therefore, experiments should be designed to understand the influence of environment on the aggressiveness mechanisms of the pathogen.

\section{The possibility of phytotoxin-induced pathogenicity}

Phytotoxins produced by fungal pathogens facilitate colonization of host tissues thus contributing to pathogenicity, which may or may not be host-specific (Berestetskiy 2008, Stergiopoulos et al. 2013). Usually these secondary metabolites interrupt the metabolic activities of the plant by weakening the defence against the pathogens. Some species in Botryosphaeriaceae produce exopolysaccharides, which might be directly linked to the pathogenicity of the fungus. For example, Lasiodiplodia theobromae has been reported to produce exopolysaccharides involved in pathogenesis (Barbosa et al. 1996, 2003).

Several studies have been conducted to understand the effect of phytotoxins produced by species of Botryosphaeriaceae on grapevine. Martos et al. (2008) conducted a study on five Botryosphaeriaceae species (B. dothidea, D. seriata, Spencermartinsia viticola, $N$. luteum and $N$. parvum). The phytotoxins produced by $N$. luteum and $N$. parvum are lipophilic, low molecular weight compounds and their phytotoxicity has been shown in plant assays. Evidente et al. (2010) identified a number of potential phytotoxins produced by $N$. parvum on grapevines. However, they did not prove that they were phytotoxic to grapevines. Several known phytotoxins have been identified in Diplodia seriata, such as isocoumarins and melleins (Djoukeng et al. 2009).

To study and understand pathogenicity it is important to choose the most suitable pathogenicity tests for the species to be studied. In the following section, we discuss different approaches used to test pathogenicity. 


\section{Pathogenicity and aggressiveness assays}

Various types of pathogenicity tests are used to determine the level of aggressiveness in plant pathogens. The tests can be either in vivo, where plants are inoculated in the field or in a greenhouse, or in vitro, where the tests are carried out on plant parts under controlled laboratory conditions. The main disadvantage of in vivo tests is that environmental factors cannot be controlled. Although environmental conditions can be controlled in in vitro tests, such tests would be expected to induce stress on the plant part to be tested (Begoude et al. 2010, Amponsah et al. 2012, Whitelaw-Weckert et al. 2013).

The types of tissue inoculated in pathogenicity tests vary according to the disease. These can be mature wood, succulent green shoots, fruits, leaves or inflorescences (Brown-Rytlewski et al. 2009). Inoculum can be either mycelial plugs or conidial suspensions that are applied to either wounded or non-wounded plant parts. The most commonly used method for testing pathogenicity in species of Botryosphaeriaceae consists of applying an agar plug colonized by the test fungus to a wound on the host (Brown-Rytlewski et al. 2009, Wunderlich et al. 2011, Linaldeddu et al. 2015). This method is simple and since many species of Botryosphaeriaceae are considered to be wound pathogens (Amponsah et al. 2012, Yan et al. 2013) it has been argued that it represents the natural mode of infection. However, it does have some serious drawbacks and these relate to the amount of inoculum and associated nutrient source. In this approach, a large amount of inoculum is applied to a wound and supplied with a vast quantity of nutrients. Under such conditions, it is likely that even a weak pathogen will be able to cause disease. Nevertheless, this method is easy and, depending on how the results are assessed and interpreted, it can give an indication of the ability of the fungus to cause disease and can also provide some measure of the amount of disease.

When spore suspensions are used as inoculum, nutrient status can be controlled to a certain extent. Thus, the suspension can be prepared in a medium with different amounts of nutrients, or with no extra nutrients. Applications of spore suspensions can also be used to measure the latent period inside the host tissue (Wunderlich et al. 2011, Whitelaw-Weckert et al. 2013). One major disadvantage of this method is that some fungi do not sporulate in culture. Irrespective of the type of inoculum used, the amount applied on the infection site plays a vital role. Excessive amounts can result in false positives, while too little can lead to negative conclusions. For example, a highly aggressive strain applied at low inoculum levels could result in little or no disease, whereas a weak pathogen applied as a massive amount of inoculum supplied with large amounts of nutrients could result in disease. For the Botryosphaeriaceae there is a clear need for studies aimed at developing pathogenicity tests that can be used to determine comparative aggressiveness of species and isolates.

\section{Conclusions}

The roles played by species of Botryosphaeriaceae vary with their ecological niche. As endophytes and pathogens their relationship with the plant should be studied in detail. In general it has been suggested that endophytes are capable of living inside a plant as a symbiont facilitating nutrient uptake by the host plant and exerting antagonistic effects on other phytopathogens. However, for Botryosphaeriaceae species these aspects have not been proven. Botryosphaeriaceous taxa as plant pathogens has generated considerable interest as an area for study, but still it is unknown what are the factors that trigger these fungi to change their life-style from endophytic to pathogenic. It appears that changes in environmental factors have an important effect on disease development and this may be due to a breakdown of plant defences against the pathogen. Considering the importance attributed to these fungi, there is a need for studies aimed at understanding the effects of environmental factors on disease development. Whole-genomic, metagenomics and proteogenomic analysis may help to explain the changes in gene expression under various environmental conditions and how these affect biochemical expressions in hostpathogen interactions.

Species of the family Botryosphaeriaceae have a wide range of hosts. Individual species have the ability to infect several different host species. In addition, these species have a wide 
geographical distribution. Because of this, studies aimed at a single species cannot be extrapolated to make firm conclusions about aggressiveness of the entire family. Therefore, further studies are required with well-designed pathogenicity tests to understand the differences in aggressiveness of each species and variability within a species. To obtain desirable outcomes it is important to have statistically suitable sample sizes and it is necessary to formulate clear hypotheses to be tested with appropriate experimental models. Changes in aggressiveness of opportunistic fungi as a result of global warming would be an interesting field for further studies.

\section{Acknowledgements}

The project was funded by Beijing Nova Program (Z141105001814047), CARS-30, JNKYT201605 and KJCX20140402. We are grateful to the Mushroom Research Foundation, Chiang Rai, Thailand. K. D. Hyde thanks the Chinese Academy of Sciences, project number 2013T2S0030, for the award of Visiting Professorship for Senior International Scientists at Kunming Institute of Botany. The authors have no conflict of interest to declare.

\section{References}

Agrios GN. 2005 - Plant pathology (Vol. 5). Burlington, Elsevier Academic Press.

Álvarez-Loayza P, White Jr JF, Torres MS, Balslev H, Kristiansen T, Svenning J, Gil N. 2011 Light converts endosymbiotic fungus to pathogen, influencing seedling survival and nichespace filling of a common tropical tree, Iriartea deloidea. PLoS ONE 6,e16386.doi: 10.1371/journal. pone. 0016386.

Alves A, Linaldeddu BT, Deidda A, Scanu B, Phillips AJL. 2014 - The complex of Diplodia species associated with Fraxinus and some other woody hosts in Italy and Portugal. Fungal Diversity 67, 143-156.

Amponsah NT, Jones EE, Ridgway HJ, Jaspers MV. 2012 - Susceptibility of grapevine tissues to Neofusicoccum luteum conidial infection. Plant Pathology 61, 719-729.

Barbosa AM, Dekker RF, St Hardy GE. 1996 - Veratryl alcohol as an inducer of laccase by an ascomycete, Botryosphaeria sp., when screened on the polymeric dye Poly R-478. Letters in Applied Microbiology 23, 93-96.

Barbosa AM, Steluti RM, Dekker RFH, Cardoso MS, Corradi da Silva MLC. 2003 - Structural characterization of Botryosphaeran: a $(10 / 3 ; 10 / 6)-b-D$ glucan produced by the ascomyceteous fungus, Botryosphaeria sp. Carbohydrate Research 338, 1691-1698.

Barr ME.1987 -Prodomus to the class Loculoascomycetes. Published by the author, Amherst, MA.

Begoude BAD, Slippers B, Wingfield MJ, Roux J. 2011 - The pathogenic potential of endophytic botryosphaeriaceous fungi on Terminalia species in Cameroon. Forest Pathology41, 281292.

Berestetskiy AO. 2008 - A review of fungal phytotoxins: from basic studies to practical use. Applied Biochemistry and Microbiology 44, 453-465.

Brown-Rytlewski DE, McManus PS. 2009 - Virulence of Botryosphaeria dothidea and Botryosphaeria obtusa on apple and management of stem cankers with fungicides. Plant Disease 84, 1031-1037.

Casadevall A. 2009 - Determinants of virulence in the pathogenic fungi. Fungal Biology Reviews 21, 130-132.

Chen SF, Morgan DP, Michailides TJ. 2014 - Botryosphaeriaceae and Diaporthaceae associated with panicle and shoot blight of pistachio in California, USA. Fungal Diversity 67, 157-179.

Crous PW, Fourie PH, Damm U. 2007 - Botryosphaeriaceae as potential pathogens of Prunus species in South Africa, with descriptions of Diplodia africana and Lasiodiplodia plurivora sp. nov. Mycologia 99, 664-680.

D'Arcy CJ, Eastburn DM, Schumann GL. 2001 - Illustrated Glossary of Plant Pathology. The Plant Health Instructor. DOI: 10.1094/PHI-I-2001-0219-01. Available at http://www.apsnet.org/edcenter/illglossary/Pages/default.aspx. 
Desprez-Loustau, ML, Marçais B, Nageleisen LM, Piou D, Vannini A. 2006 - Interactive effects of drought and pathogens in forest trees. Annals of Forest Science 63, 597-612.

Djoukeng JD, Polli S, Larignon P, Abou-Mansour E. 2009 - Identification of phytotoxins from Botryosphaeria obtusa, a pathogen of black dead arm disease of grapevine. European Journal of Plant Pathology 124, 303-308.

Evidente A, Punzo B, Andolfi A, Cimmino A, Melck D, Luque J. 2010 - Lipophilic phytotoxins produced by Neofusicoccum parvum, a grapevine canker agent. Phytopathologia Mediterranea 49, 74-79.

Faeth SH, Fagan WF. 2002 - Fungal endophytes: common host plant symbionts but uncommon mutualists. Integrative and Comparative Biology 42, 360-368.

Farr DF, Rossman AY. Fungal Databases, Systematic Mycology and Microbiology Laboratory, ARS, USDA. Online available at http://nt.ars-grin.gov/fungaldatabases/. Accessed on August 25, 2016.

Félix C, Duarte AS, Vitorino R, Guerreiro AC, Domingues P, Correia AC, Alves A, Esteves AC. 2016 - Temperature modulates the secretome of the phytopathogenic fungus Lasiodiplodia theobromae. Frontiers in Plant Science 7, 1096. http://doi.org/10.3389/fpls.2016.01096.

Hantsch L, Braun U, Haase J, Purschke O, Scherer-Lorenzen M Bruelheide H. 2014 - No plant functional diversity effects on foliar fungal pathogens in experimental tree communities. Fungal Diversity 66, 139-151.

Hartill WFT, Everett KR. 2002 - Inoculum sources and infection pathways of pathogens causing stem-end rots of 'Hass' avocado (Persea Americana).New Zealand Journal of Crop and Horticultural Science30, 249-260.

Hyde KD, Nilsson RH, Alias SA, Ariyawansa HA, Blair JE, Cai L, de Cock AWAM, Dissanayake AJ, Glockling SL, Goonasekara ID, Gorczak M, Hahn M, Jayawardena RS, van Kan JAL, Laurence MH, Lévesque CA, Li XH, Liu JK, Maharachchikumbura SSN, Manamgoda DS, Martin FN, McKenzie EHC, McTaggart AR, Mortimer PE, Nair PVR, Pawłowska J, Rintoul TL, Shivas RG, Spies CFJ, Summerell BA, Taylor PWJ, Terhem RB, Udayanga D, Vaghefi N,Walther G,WilkM,WrzosekM, Xu JC, Yan JY, Zhou N. 2014 - One stop shop: backbones trees for important phytopathogenic genera: I. Fungal Diversity $67,21-125$.

Hyde KD, Soytong K. 2008 - The fungal endophyte dilemma.Fungal Diversity33, 163-173.

Jami F, Slippers B, Wingfield MJ, Gryzenhout M. 2013 - Greater Botryosphaeriaceae diversity in healthy than associated diseased Acacia karroo tree tissues. Australasian Plant Pathology 42, 421-430.

Jeewon R, Ittoo J, Mahadeb D, Jaufeerally-Fakim Y, Wang H, Liu A. 2013 - DNA Based identification and phylogenetic characterization of endophytic and saprobic fungi from Antidesmamada gascariense, a medicinal plant in Mauritius. Journal of Mycology 2013, article 781914, 1-10.

Li G, Arnold RJ, Liu F, Li J, Chen S. 2015 - Identification and pathogenicity of Lasiodiplodia species from Eucalyptus urophylla $\times$ grandis, Polysciasbalfouriana and Bougainvillea spectabilis in southern China. Journal of Phytopathology 163, 956-967.

Linaldeddu BT, Deidda A, Scanu B, Franceschini A, Serra S, Berraf-Tebbal A, Zouaoui Boutiti M, Ben Jamâa ML, Phillips AJL. 2015 - Diversity of Botryosphaeriaceae species associated with grapevine and other woody hosts in Italy, Algeria and Tunisia, with descriptions of Lasiodiplodia exigua and Lasiodiplodia mediterranea sp. nov. Fungal Diversity 71, 201-214.

Liu JK, Phookamsak R, Doilom M, Wikee S, Li YM, Ariyawansa H, Boonmee S, Chomnunti P, Dai DQ, Bhat JD, Romero AI. 2012 - Towards a natural classification of Botryosphaeriales. Fungal Diversity 57, 149-210. 
Lorenzini M, Cappello MS, Zapparoli G. 2015 - Isolation of Neofusicoccum parvum from withered grapes: strain characterization, pathogenicity and its detrimental effects on Passito wine aroma. Journal of Applied Microbiology 199, 1335-1344.

Machado AR, Pinho DB, Pereira OL. 2014 - Phylogeny, identification and pathogenicity of the Botryosphaeriaceae associated with collar and root rot of the biofuel plant Jatrophacurcas in Brazil, with a description of new species of Lasiodiplodia. Fungal Diversity 67, 231-247.

Mareeswaran J, Nepolean P, Jayanthi R, Premkumar SAR, Radhakrishnan B. 2015 - In vitro studies on branch canker pathogen (Macrophoma sp.) infecting tea. Journal of Plant Pathology and Microbiology 6, 284, doi: 10.4172/2157-7471.1000284.

Marques MW, Lima NB, de Morais Jr MA, Michereff SJ, Phillips AJ, Câmara MP. 2013 Botryosphaeria, Neofusicoccum, Neoscytalidium and Pseudofusicoccum species associated with mango in Brazil. Fungal Diversity 61, 195-208.

Martos S, Andolfi A, Luque J, Mugnai L, Surico G, Evidente A. 2008 - Production of phytotoxic metabolites by five species of Botryosphaeriaceae causing decline on grapevines, with special interest in the species Neofusicoccum luteum and N. parvum. European Journal of Plant Pathology121, 451-461.

McDonald BA. 2004 - Population genetics of plant pathogens. The Plant Health Instructor, doi: 10.1094. PHI-A-2004-0524-01, online available at: http://www.apsnet.org/edcenter/advanced/topics/popgenetics/Pages/default.aspx. Accessed on July, 23, 2016.

Mohali SR, Slippers B, Wingfield MJ. 2009 - Pathogenicity of seven species of the Botryosphaeriaceae on Eucalyptus clones in Venezuela. Australasian Plant Pathology 38, 135-140.

Nair DN, Padmavathy S. 2014 - Impact of endophytic microorganisms on plants, environment and humans. The Scientific World Journal 2014, online available at: http://dx.doi.org/10.1155/2014/250693.

Netto MS, Assunção IP, Lima GS, Marques MW, Lima WG, Monteiro JH, de Queiroz, Balbino V, Michereff SJ, Phillips AJ, Câmara MP. 2014 - Species of Lasiodiplodia associated with papaya stem-end rot in Brazil. Fungal Diversity 67, 127-141.

Paoletti E, Anselmi N, Franceschini A. 2007 - Pre-exposure to ozone predisposes oak leaves to attacks by Diplodia corticola and Biscogniauxia mediterranea. The Scientific World Journal 7, 222-230.

Pariaud B, Ravigné V, Halkett F, Goyeau H, Carlier J, Lannou C. 2009 - Aggressiveness and its role in the adaptation of plant pathogens. Plant Pathology 58, 409-424.

Phillips AJL, Alves A, Abdollahzadeh J, Slippers B, Wingfield MJ, Groenewald JZ, Crous PW. 2013 - The Botryosphaeriaceae: genera and species known from culture. Studies in Mycology 76, 51-167.

Piao S, Ciais P, Huang Y, Shen Z, Peng S, Li J, Zhou L, Liu H, Ma Y, Ding Y, Friedlingstein P. 2010 - The impacts of climate change on water resources and agriculture in China. Nature467, 43-51.

Ragazzi A, Moricca S, Dellavalle I. 1999a - Interactions between Quercus spp. and Diplodia mutila under water stress conditions. Journal of Plant Diseases and Protection 106, 495500.

Ragazzi A, Moricca S, Della Valle I. 1999b - Water stress and the development of cankers by Diplodia mutila on Quercus robur. Journal of Phytopathology147, 425-428.

Rodas CA, Slippers B, Gryzenhout M, Wingfield MJ. 2009 - Botryosphaeriaceae associated with Eucalyptus canker diseases in Colombia. Forest Pathology 39, 110 123.

Sánchez ME, Venegas J, Romero MA, Phillips AJL, Trapero A. 2003 - Botryosphaeria and related taxa causing oak canker in south western Spain.Plant Disease 87, 1515-1521. 
Sakalidis ML, St. J Hardy GE, Burgess TI. 2011-Class III endophytes, clandestine movement amongst hosts and habitats and their potential for disease; a focus on Neofusicoccum australe. Australasian Plant Pathology 40, 510-521.

Schoeneweiss DF. 1981 - The role of environmental stress in diseases of woody plants. Plant Disease 65, 308-314.

Slippers B, Wingfield MJ. 2007-Botryosphaeriaceae as endophytes and latent pathogens of woody plant: diversity, ecology and impact. Fungal Biology Reviews 21, 90-106.

Smith T. 1914 - An attempt to interpret present-day uses of vaccines. Journal of the American Medical Association 60, 1591-1599.

Smith H, Wingfield MJ, Crous PW, Coutinho TA. 1996a - Sphaeropsis sapinea and Botryosphaeria dothidea endophytic in Pinus spp. and Eucalyptus spp. in South Africa. South African Journal of Botany 62, 86-88.

Smith H, Wingfield MJ, Petrini O. 1996b - Botryosphaeria dothidea, endophytic in Eucalyptus grandis, and Eucalyptus nitens in South Africa. Forest Ecology and Management 89, 189195.

Stergiopoulos I, Collemare J, Mehrabi R, De Wit PJ.2013- Phytotoxic secondary metabolites and peptides produced by plant pathogenic Dothideomycete fungi. FEMS Microbiology Reviews 37, 67-93.

Trakunyingcharoen T, Cheewangkoon R, To-anun C. 2015 - Phylogenetic study of the Botryosphaeriaceae species associated with avocado and para rubber in Thailand. Chiang Mai Journal of Science 42, 104-116.

Úrbez-Torres JR. 2011 - The status of Botryosphaeriaceae species infecting grapevines. Phytopathologia Mediterranea 50, 5-45.

Úrbez-Torres JR, Battany M, Bettiga LJ, Gispert C, McGourty G, Roncoroni J, Smith R J, Verdegaal P, Gubler WD. 2010a-Botryosphaeriaceae species spore-trapping studies in California vineyards. Plant Disease 94, 717-724.

Úrbez-Torres JR, Bruez, E, Hurtado J, Gubler WD. 2010b - Effect of temperature on conidial germination of Botryosphaeriaceae species infecting grape vines. Plant Disease 94, 14761484.

Úrbez-Torres JR, Rooney-Latham S, Eskalen A, Smith RJ, Gubler WD. 2010c - Evaluation of pruning wound susceptibility and protection against fungi associated with grapevine trunk diseases. American Journal of Viticulture 61, 113-119.

Whitelaw-Weckert MA, Rahmana L, Applebya LM, Halla A, Clarka AC, Waitea A, Hardiec WJ.2013 - Co-infection by Botryosphaeriaceae and Ilyonectria spp. fungi during propagation causes a decline of young grafted grapevines. Plant Pathology 62, $1226-1237$.

Wingfield MJ, Roux J, Wingfield BD. 2011 - Insect pests and pathogens of Australian acacias grown as non-natives - an experiment in biogeography with far-reaching consequences. Diversity and Distributions 17, 968-977.

Wunderlich N, Ash GJ, Steel CC, Raman H, Cowling A, Savocchia S. 2011 - Refining the biological factors affecting virulence of Botryosphaeriaceae on grapevines. Annals of Applied Biology 159, 467-477.

Xu C, Zhang H, Zhou Z, Hu T, Wang S, Wang Y, Cao K. 2015 - Identification and distribution of Botryosphaeriaceae species associated with blueberry stem blight in China.European Journal of Plant Pathology 143, 737-752.

Yan JY, Xie Y, Zhang W, Wang Y, Liu JK, Hyde KD, Seem RC, Zhang GZ, Wang ZY, Yao SW, Bai XJ, Dissanayake AJ, Peng YL, Li XH. 2013 - Species of Botryosphaeriaceae involved in grapevine dieback in China. Fungal Diversity 61, 221-236.

Zinsser H, Bayne-Jones S. 1939 - A Textbook of Bacteriology, D. Appleton-Century Company Inc., New York, edition 7, 313-347. 